\title{
ТАКТИЧЕСКИЕ ОСОБЕННОСТИ ОСМОТРА НЕОПОЗНАННОГО ТРУПА НА МЕСТЕ ЕГО ОБНАРУЖЕНИЯ
}

\section{TACTICAL FEATURES OF THE EXAMINATION OF AN UNIDENTIFIED CORPSE AT THE SCENE OF ITS DISCOVERY}

A. Khitev

Summary: Investigation of crimes related to the discovery of unidentified corpses has become a serious problem in the Russian Federation, primarily due to the significant increase in their detection. The work on solving murders related to the unknown disappearance of citizens is becoming more relevant. In such cases, if there is a forensic medical examination report on the violent nature of the death, there is no doubt that the crime was committed, but the lack of information about the identity of the victim does not allow us to determine the circle of his connections that need to be checked for involvement in the Commission of the crime. The article discusses issues related to the features of the examination of an unidentified corpse at the site of its discovery, describes in detail the actions of the investigative task force on the tactics of examining an unidentified corpse, removing and packing clothes and shoes of the corpse, as well as the conditions for collecting and storing samples of biological material from unidentified corpses without rotten changes, skeletonized, rottenly modified or mummified corpses for registration in the DNA database of unidentified corpses.

Keywords: unidentified body, inspection of the scene, detection, fixation and removal of traces.

$\mathrm{B}$ последние годы расследование преступлений, связанных с обнаружение неопознанных трупов стало представлять серьезную проблему на территории Российской Федерации, прежде всего в связи со значительным ростом их обнаружения. Также большую актуальность приобретает работа по раскрытию убийств, связанных с безвестным исчезновением граждан.

Сложность таких дел в дефиците информации, необходимой для полноценного выдвижения и отработки версий по делу. В таких делах, при наличии заключения судебно-медицинской экспертизы о насильственном характере смерти не возникает сомнений в совершении преступления, однако отсутствие информации о личности убитого, не позволяет определить круг его связей, которые нуждаются в проверке на причастность к совершению преступления.

При рассмотрении вопроса о расследовании преступлений, стоит выделить факт того, что данную деятельность осуществляют специальные субъекты, наделенные
Хитев Алексей Павлович

Старший преподаватель, Владимирский юридический институт Федеральной службы исполнения наказания hitevap@mail.ru

Аннотация: Расследование преступлений, связанных с обнаружение неопознанных трупов стало представлять серьезную проблему на территории Российской Федерации, прежде всего в связи со значительным ростом их обнаружения. Большую актуальность приобретает работа по раскрытию убийств, связанных с безвестным исчезновением граждан. В таких делах, при наличии заключения судебно-медицинской экспертизы о насильственном характере смерти не возникает сомнений в совершении преступления, однако отсутствие информации о личности убитого, не позволяет определить круг его связей, которые нуждаются в проверке на причастность к совершению преступления.

В статье рассматриваются вопросы, связанные с особенностями осмотра неопознанного трупа на месте его обнаружения, подробно описываются действия следственно-оперативной группы по тактике осмотра неопознанного трупа, изъятия и упаковки одежды и обуви трупа, а также условия сбора и хранения образцов биологического материала от неопознанных трупов без гнилостных изменений, скелетированных, гнилостно измененных или мумифицированных трупов для постановки на учет в банк данных ДНК неопознанных трупов.

Ключевые слова: неопознанный труп, осмотр места происшествия, обнаружение, фиксация и изъятие следов.

комплексом специфических полномочий, а сам процесс расследования, для более точного выявления лиц, причастных к совершению преступлений и фактов, способствующих раскрытию, должен идти непрерывно [2].

Таким образом, в данном случае, помимо основной цели - раскрытия преступления - установления и изобличения виновного, появляется промежуточная, имеющая самостоятельное значение цель - установление личности неопознанного трупа, его идентификация.

Для полноценного достижения поставленных целей необходимо провести сбор информации не только о внешних чертах исчезнувшего, к которым относят особые приметы: одежду в которой лицо находилось, цвет глаз, волос и рост, но и специфические черты: особенности походки, разговора, курение, привычки, отношение к правоохранительным органам и др. При рассмотрении сведений такого рода, необходимо понимать, что от слаженных и отработанных действий правоохранительных органов, будет зависеть процесс раскрытия, так как на 
практике, потерпевший находится в некоторой связи с преступником [1].

Первым и единственным на первоначальном этапе расследования источником информации является сам труп и место его обнаружения, поэтому решающее значение по таким делам приобретает качественный и своевременный осмотр места происшествия.

Осмотр места происшествия, связанный с обнаружением трупа, осуществляет следственно-оперативная группа, в состав которой входят следователь следственного комитета, судебно-медицинский эксперт, эксперткриминалист, сотрудник уголовного розыска, кинолог (при формировании СОГ следователь вправе привлечь к ОМП специалиста ЭКЦ нужного профиля (медика-криминалиста, биолога)).

Осмотр места происшествия проводится по общим правилам в установленном порядке, в ходе которого выполняется фотографирование (панорамные, обзорные, узловые и детальные снимки) и видеосъемка трупа и прилегающих участков местности, обнаруженных вещественных доказательств. Фото- и видеосъемка применяется и в дальнейшем при осмотре трупа - выполняются опознавательные разноракурсные снимки головы трупа (в фас, профиль и полупрофиль), повреждений и особых примет на трупе.

Далее следует процесс составления план-схемы места происшествия, где следователь должен отразить ориентиры, окружающие место происшествия, положение трупа относительно этих ориентиров, расположение обнаруженных предметов, что в дальнейшем, позволит прийти к выводу о механизмах, при которых было совершено преступление.

Целью этапа дактилоскопирования трупа является идентификация отпечатков кистей рук неопознанного трупа для внесения и проверки их в базе данных автоматизированной дактилоскопической система АДИС-Папилон, с последующим выявлением лица.

Затем производится осмотр трупа судебным медиком, в ходе которого описываются:

1. конкретное место обнаружения трупа, с привязкой на местности к постоянным и значимым ориентирам (дома, сооружения, стационарные части квартиры или дома, к сторонам света - если на открытой местности и т.д.);

2. положение, поза трупа;

3. общие и частные особенности одежды, обуви и иных предметов при трупе;

4. биологическая характеристика трупа (пол, расовый тип и возраст, окружность головы, длина тела и стоп; анатомические особенности, включая при- меты) и трупных явлений

5. признаки внешности, описанные методом словесного портрета по системе, принятой в криминалистике и судебной медицине (особые приметы фотографируются и зарисовываются);

6. повреждения, которые фотографируются с использованием масштабной линейки и зарисовываются на контурных схемах частей тела человека.

После окончания осмотра трупа, осматривается «ложе» трупа и прилегающая местность, при этом описываются предметы, обнаруженные вблизи трупа.

При обнаружении трупов с изменениями строения мышечного аппарата, кожного покрова и органов вследствие процесса гниения, обгоревших участков кожного покрова или скелетирования, необходимо более тщательно осмотреть окружающую местность. Учитывая, что части трупа, как правило, растаскиваются животными, границы осмотра должны быть максимально расширены, при необходимости для прочесывания местности привлекать дополнительные силы полиции, общественность. Для полноценного расследования и собирания информации, необходимо исследовать объекты, находящиеся за пределами границы осмотра [3].

По окончания осмотра места происшествия решается вопрос об объектах, подлежащих изъятию. Изымаются все предметы, обнаруженные при трупе и возле него.

Вопрос об изъятии одежды и обуви должен решаться в каждом случае индивидуально. Представляется, что целесообразно сразу изымать предметы одежды и обуви, которые могут быть утеряны при транспортировке и хранении, а также в случае опасности утерять находящиеся на одежде наложения.

Не следует изымать одежду с повреждениями, поскольку в этом случае, исследование одежды в комплексе с трупов в ходе судебно-медицинской экспертизы позволит тщательнее описать взаиморасположение повреждений на трупе и одежде и точнее определить механизм образования повреждений.

Изымаемые объекты должны тщательно упаковываться, опечатываться бирками с печатью следственного комитета и подписями понятых и следователя. На бирке должно быть отражено - время и место осмотра, название изымаемого объекта. Биологические объекты должны упаковываться так, чтобы было исключено их загнивание (в бумажные пакеты или картонные коробки).

После осмотра на месте обнаружения тело трупа или его останки направляются в морг для проведения судебно-медицинской экспертизы, принимая меры предосторожности для предотвращения повреждения целост- 
ности, механических повреждений, загрязнения или утраты отдельных его частей, вещей и предметов, изъятых с места обнаружения. Если тело трупа находилось в воде или другой агрессивной, или консервирующей среде, то для сохранения состояния внешних признаков немедленно проводится фотосъемка по правилам опознавательной, сигналетической фотосъемки. Видеозапись может быть использована для захвата внешних объектов и признаков.

Если тело трупа не может быть осмотрено на месте обнаружения, то его осматривают до вскрытия в соответствии с вышеуказанными правилами в больнице или морге. Если нет возможности провести идентификационную фотосъемку и дактилоскопию трупа на месте обнаружения, то это делается в морге после соответствующего туалета лица и обработки пальцев рук.

Сбор и хранение образцов биологического материала от неопознанных трупов осуществляется судебно-медицинским экспертом.

При направлении неустановленного трупа для исследования в бюро СМЭ в обязательном порядке необходимо ставить перед экспертом задачу об изъятии и хранении биологических объектов умершего.

В случае невозможности установления личности неопознанного трупа в течение 2 месяцев после его обнаружения сотрудники розыскных подразделений обязаны направлять в ЭКЦ субъекта РФ изъятые судебно-медицинским экспертом биологические объекты умершего для внесения в банк данных ДНК неопознанных трупов.

Условия сбора и хранения биологических образцов от неопознанных трупов должны гарантировать их сохранность. Об изъятии биологических образцов от неопознанного трупа в обязательном порядке должна делается отметка в акте судебно-медицинского исследования, либо заключении эксперта. Каждый отобранный образец должен быть упакован в отдельный пакет, чтобы не допустить перекрестной генетической контаминации (двойные полиэтиленовые пакеты, пластиковая емкость и полиэтиленовый пакет, фольга и двойные полиэтиленовые пакеты при упаковке костных образцов и т.п.).

Все отобранные образцы должны быть четко маркированы, указывается место и дата обнаружения трупа, № уголовного дела (в случае его наличия), ФИО эксперта и дата забора образцов.

В случае отбора биологического материала от двух или более неопознанных трупов в целях предотвращения перекрестной генетической контаминации при работе с каждым трупом использовать отдельные защитные перчатки и инструментарий. При невозможно- сти замены инструментария необходимо его тщательно промыть водой и обработать хлорсодержащими дезинфицирующими средствами.

Доставку отобранного биологического материала к местам хранения образцов осуществлять в термоизолированных контейнерах с сухим (или обычным) льдом, чтобы исключить размораживание объектов исследования во время транспортировки.

Если труп не имеет гнилостных изменений отбирают образцы крови:

1. из сердечных полостей, более крупных, по отношению к другим, сосудов отбирают по 2,5-5 мл не загустевшей крови, после чего ее помещают на центральную часть стерильной марлевой салфетки в диаметр 2-3 мм (не допускается обработка марлевых салфеток какими-либо консервантами и дезинфицирующими средствами;

2. марлевые салфетки с нанесенными образцами крови высушивают при комнатной температуре, избегая попадания прямых солнечных лучей и загрязнений;

3. хранятся высушенные марлевые салфетки в бумажном конверте при комнатной температуре.

Если труп гнилостно измененный или мумифицированный отбирают образцы мягких тканей:

1. из участков кожных покровов, органов, мышечной структуры, наименее подверженных гнилостным изменениям отбирают по 2-3 фрагмента мягких тканей величиной 2,0×2,0×0,5 см или массой 50 г;

2. мягкие ткани замораживаются с помощью жидкого азота либо помещаются в морозильную камеру при температуре -30о C;

3. хранятся замороженные ткани при -30о С не более 1 года, для более длительного хранения необходимо обеспечить температуру -700С.

Если труп скелетированный, гнилостно измененный или мумифицированный и установлено, что труп находился во внешней агрессивной среде не более 1 года, то отбор ногтевых пластин и волосяных покровов происходит следующим образом:

1. отбирают 2-3 ногтевых пластины вместе с ростковым слоем; 50-60 волос с луковицами;

2. ногтевые пластины и луковицы замораживаются;

3. хранятся замороженные ткани при -30оС не более 1 года, для более длительного хранения необходимо обеспечить температуру -700С.

Если труп скелетированный, гнилостно измененный или мумифицированный отбирают образцы костной ткани:

1. отбор фрагментов в 2-3 экземплярах частей или 
целых костей, по составу имеющие губчатое вещество (ребра) общей массой не более 20-50 г;

2. кости замораживаются;

3. хранятся замороженные ткани при -30оС не более 1 года, для более длительного хранения необходимо обеспечить температуру -700С.

Проведенное исследование не может полноценно раскрыть комплекс проблемных вопросов, возникающих в работе следователя по расследованию преступлений, деятельности по опознанию трупа и последующим установлением личности в связи с тем, что сложность и неоднозначность вопросов подобного рода индивидуальна для отдельных уголовных дел.
Разработанные на данный момент методики расследования преступлений против личности, жизни и здоровья граждан, могут только механически способствовать правильным действиям следователя, а также, теоретически упростить процесс сбора сведений об обстоятельствах дела, требующихся для раскрытия преступления и определения виновности лица, его совершившего. Следователь самостоятельно определяет объем расследования и пределы применения конкретных методических рекомендаций, исходя из собственного опыта и исходя из интересов обеспечения полноты, объективности и всесторонности расследования уголовного дела, что требует высокого профессионализма, глубоких знаний и ответственности.

\section{ЛИТЕРАТУРА}

1. Расследование преступлений, совершаемых в органах и учреждениях уголовно-исполнительной системы: практическое руководство для следователей, дознавателей правоохранительных органов и оперативных сотрудников уголовно-исполнительной системы / под ред. Е.П. Ищенко. - М.: Юрлитинформ, 2013. - С. 202

2. Тимонина И.В. Моделирование и проверка версий о заказном характере убийств в условиях типичных следственных ситуаций // Следователь. 2005 . № 1. C.19.

3. Тимонина И.В. Моделирование следственных действий по делам о заказных убийствах // Следователь. 2005. № 9. С. 32.

(с) Хитев Алексей Павлович (hitevap@mail.ru).

Журнал «Современная наука: актуальные проблемы теории и практики»

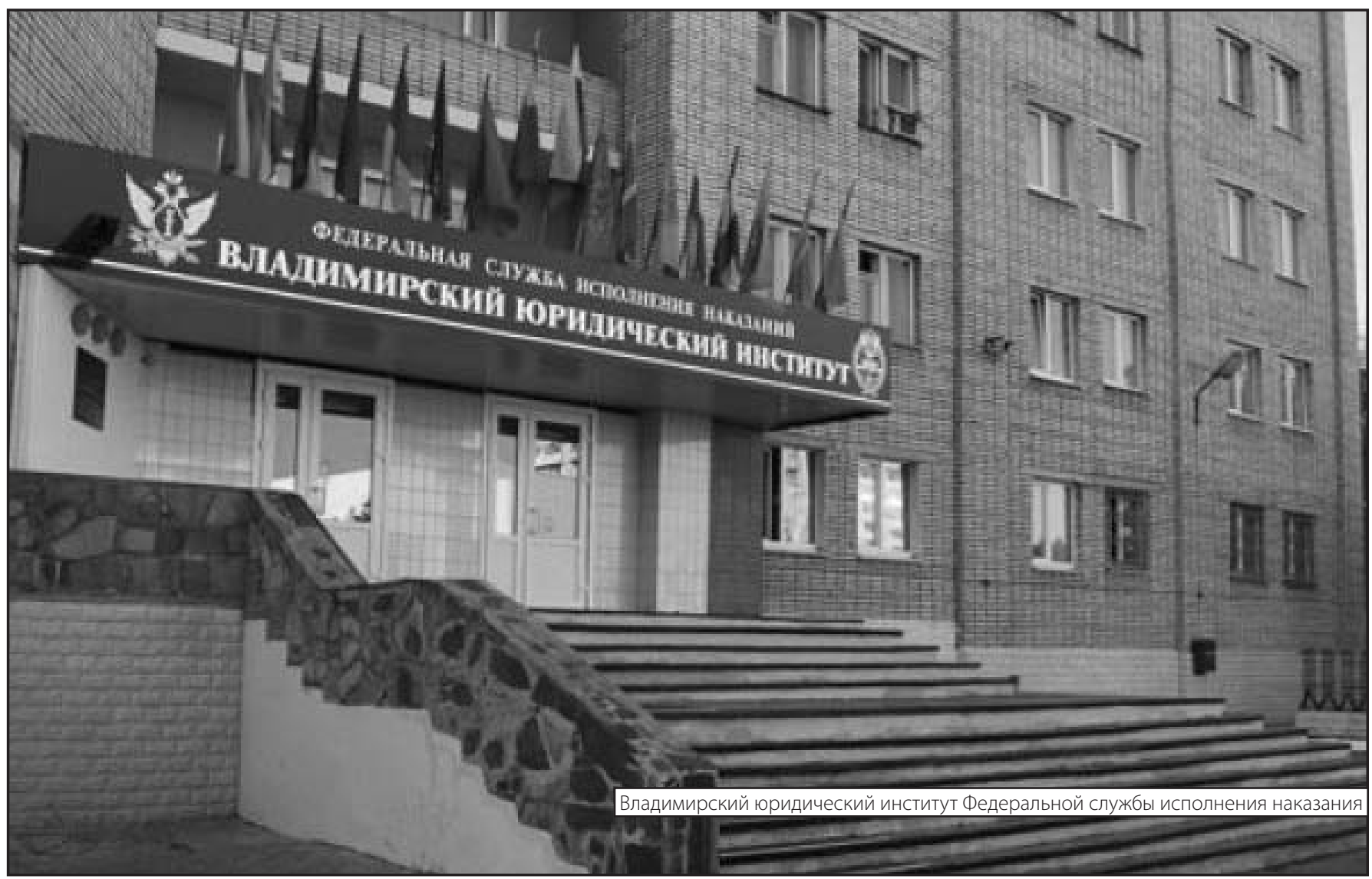

